\title{
Chapter 19 \\ Sociodrama, Activism, and Role Training to Empower Communities
}

\begin{abstract}
This chapter will highlight the use of role-playing, especially sociodrama and role training in community empowerment and social activist movements. Historical context will be provided for the traditions of using drama, theater, and role-play in social work and social activism including Jacob Moreno's vision of the theater as a modality for societal change. The sociodramatic approach will be outlined with focus on its utility in community settings as an experiential and communal experience of social action. Multiple examples of sociodrama or role training in communities are depicted with an emphasis on its adaptability for different settings and its effectiveness at empowering people. Examples include its application with youth, law enforcement, intergenerational dialogues, domestic violence response teams, undocumented immigrant communities, social work students, and to empower advocacy with employers, insurance providers, funders, or policy makers.
\end{abstract}

Keywords Sociodrama $\cdot$ Social activism $\cdot$ Role training $\cdot$ Community empowerment $\cdot$ Social justice

The use of art is foundational in nearly every social movement. As such, sociodrama, a spontaneous and creative arts approach, is a fitting modality for community work related to social movements. The etymology of the word psychodrama conveys the meaning of "psyche in action", on the other hand, the term sociodrama suggests a meaning of "social in action" or "social action". Considering an etymological lens, the terms social movement, social activism, and social action all suggest a fundamental emphasis on creating action or movement within, or of, society or social groups as an end goal. It is more than fitting then that the goal of social action be achieved through the means of sociodrama and action-based group approaches. In this way, the means and the ends, as well as the process and content of community sessions, are synergistically related.

S. Giacomucci, Social Work, Sociometry, and Psychodrama, Psychodrama in Counselling, 


\subsection{Theater as a Modality for Social Activism}

Drama and the theater have traditionally played a significant role in community life tracing its histories across cultures and continents, with some of the oldest written histories coming from Ancient Egypt and Ancient Greece (Freedley \& Reeves, 1964; Leahy, 2008; McCammon, 2007; Moreno, 1972). Drama and theater existed with connections to community entertainment, religion, politics, education, psychotherapy, and social action. The use of theater in community social work can be traced back to Jane Addam's Hull House in Chicago which had a very popular theater program as early as the 1890s (Hecht, 1982). Hull House's use of theater was based on its potential of inspiring and empowering the community with an emphasis on highlighting social and political ills. "Theatre and politics are intrinsically connected. The art of politics is extremely theatrical and the art of theatre has always been infused with political relationships" (Leahy, 2008, p. 1). Many activists employ drama within their activism as a means of cultivating social change with theater; and many actors employ social or political content in their shows to produce theater with social change. Considerable overlap exists between these two worlds, nevertheless, debate remains active between actors and activists about the boundary and overlap of their domains (Schlossman, 2002).

Leahy (2008) argues that theater and politics share much in common including both fundamentally being tools of persuasion with the goals of convincing audiences to adhere to specific conclusions. Social activism, advocacy, and social movements appear to operate with similar approaches to influence the opinions of individuals, groups, or society. While traditional politics and theater both seem to adhere to their own respective scripts to persuade audiences, Moreno's Theater of Spontaneity and other therapeutic uses of theater or drama replace the script with spontaneity. Instead, they focus less on an end goal of persuasion and more on the therapeutic experience of engaging in the dramatic process. The emphasis shifts from the content or final theater production to the process of drama.

The dramatic process has the power to create change for both actors and spectators (Moreno, 1972). Aristotle wrote of the Ancient Greek theater creating catharsis within audience members as an important social function of purification (Aristotle, 1951). Moreno later noted the cathartic experience of drama for both the audience and the actors (Moreno, 1940). Moreno's original vision of his theater work (Theater of Spontaneity of Vienna in 1920s and Impromptu Theater of New York in the 1930s) was as a vehicle for creating large-scale social change and a creative revolution"I foresaw an enormous task, to change the public. It would have required a total revolution in our culture, a creative revolution. That was my goal in life" (2019, p. 213). Public psychodrama sessions were held in New York, open to anyone in the community, six nights a week between the late 1940s until the early 70s (Moreno, 2014). Though these were public community sessions, it appears that the content was mostly psychodramatic rather than sociodramatic.

In the 1960-1970s, many theater groups emerged connected to various social movements with the objective of cultivating social change (Shank, 1982). These 
included both Playback Theater in the United States and Theater of the Oppressed in South America. Perhaps Augusto Boal's Theater of the Oppressed is the most popular and most successful use of theater for social change around the world. Both Moreno and Boal's use of theater started with a vision of social change and later included models specific for psychotherapy. Nevertheless, it seems Moreno's work became much more integrated into psychotherapy (particularly in the United States) while Boal's remained focused on social change. Perhaps this differentiation can be explained by their backgrounds as Moreno was a European/American psychiatrist and pioneer of group psychotherapy while Boal was a Marxist playwright from Brazil (Oliveira \& Araujo, 2012). Theater of the Oppressed maintained a goal of social and political change, while psychodrama became focused on creating psychological change or change in small groups. Interestingly, however, the utilization of psychodrama in Brazil (which has the largest psychodrama community in the world) appears to be much less individualistic with more community focused practice addressing social and political issues. In 2001, the city of São Paulo in Brazil even held a special psychodrama day at the request of the mayor, which involved over 10,000 citizens at 158 public locations throughout the city with the topic of "ethics and citizenship" (Greeb, 2019).

\subsection{Sociodrama and Social Activism}

Psychodrama's potential for powerful catharsis is, in part, what makes it a formidable tool in psychotherapy but also limits its safe use in community groups. While psychodrama is focused on the externalization of individual issues, sociodrama dramatizes social issues. The fundamental nature of roles in psychodrama focuses on private elements of roles, while sociodrama focuses on collective elements of roles (Sternberg \& Garcia, 2000). Moreno (1943) writes that social issues cannot be adequately addressed within the confines of individual psychotherapy, instead, social issues must be addressed within community forums, preferably with sociodrama. Most would agree that psychodrama is a better approach for personal growth, while sociodrama is better designed for social change. As such, sociodrama is used much more frequently than psychodrama within social activism or public spaces.

The goals of a sociodrama enactment include expression, catharsis, insight, learning, and role training (Sternberg \& Garcia, 2000). A sociodrama does not enact any one person's story, but instead puts into action a co-created story that contains elements of the entire group's experience without using the specific details of their narratives. This creates a sense of aesthetic distance similar to the experience of watching a movie or theater play containing social themes that resemble one's personal life experience. The major difference between a sociodrama and a movie or theater performance is that the sociodrama has no script or predefined characters, and it is spontaneously improvised and co-created by the group. Here, we also touch upon a fundamental difference between sociodrama, Playback Theater, Theater of the Oppressed, and traditional theater. In the traditional theater, the script is written 
by a playwriter; Playback Theater and Theater of the Oppressed utilize an audience member's narrative as the script; and the sociodramatic script emerges from the collective conscious of the group. In some sociodramas, the theme or issue might be predetermined, but the actual script is spontaneously generated.

Sociodramatic role-plays are being used regularly in therapy, community organizing, and social activism spaces, though most often simply referred to as "roleplays" or "simulations" (Hunter \& Lakey, 2004; Jemal, Urmey, \& Caliste, 2020). Activists and sociodramatists bring community issues to life using role-plays as an educational tool which provides participants with action insights, catharsis, new perspective, and role training. Below are multiple examples of both sociodramas and sociodramatic role-plays in community settings focused on social activism, beginning with a description of the first sociodrama by Moreno. It is important to note that the experiential sociometry tools from Sects. 18.5-18.10 are especially useful to warm up community groups before moving into any type of role-play or action sociodrama.

\subsubsection{Moreno's Search for a Leader of the New World Order}

The first sociodrama session took place on April 1, 1921, in Vienna, facilitated by Jacob Moreno. This session took place at the Vienna Comedian House just a few years after the end of World War I and the collapse of the Austria-Hungarian Empire. "Postwar Vienna was seething with revolt. There was no stable government, no emperor, no king, no leader...And, like the other nations of the earth, Austria was restless, in search of a new soul" (Moreno, 2019, p. 206). Moreno describes the audience as consisting of around one thousand people including politicians, foreign dignitaries, religious leaders, and cultural leaders of Vienna. Moreno appeared on stage with no script, no actors, and with only a chair resembling a throne and a gilded crown. In his autobiography, he describes this experience in his own words:

\footnotetext{
I was entirely unprepared... But, psychodramatically speaking, I had a cast and I had a play. The audience was my cast. The people in the audience were like a thousand unconscious playwrights. The play was the situation into which they were thrown by historical events in which each of them had a real part to play. It was my aim, as we would say today, to tap sociodrama in statu nascendi and to analyze the production which emerged. If I could only succeed in turning the audience into actors, actors in their own collective drama, the collective drama of social conflict in which they were actually involved every day of their lives, then my boldness would be redeemed and the session would have accomplished something. (2019, p. 206)
}

He invited audience members to ascend from the crowd to the throne and offer a new philosophy of leadership for the new world order. "No one was prepared ahead of time. Unprepared characters acted in an unprepared play before an unprepared audience. The audience played the role of the jury" (Moreno, 2019, p. 206). Nobody won the approval of the audience-including Moreno and his spontaneous experiment. This first sociodrama resulted in newspapers harshly criticizing him, friends leaving 
him, harm to his reputation in Vienna, and a newfound commitment to spontaneous theater by Moreno and his theater group.

Though the session was described as a failure, it led to the production of the Impromptu Theater, sociodrama, and psychodrama. Most trained psychodramatists, who have the benefit of the 100 years of practice wisdom since this event, would comment on the lack of audience warm-up and the value of using doubling, mirroring, and role reversal that Moreno had not yet conceived of at that time. Consideration of the contract with the group is also significant in analyzing Moreno's failed session. The audience attended under the assumption that they would sit quietly in the role of audience, as is the informal contract they agree to in every other theater session. Moreno changed the contract and asked audience member to become not only an actor, but the protagonist of the show without proper warm-up. Perhaps Moreno was to be the most influential leader in the building that night and the session would have benefitted from him sitting on the throne. Or, maybe the crowd's inability to produce a leader was the perfect conclusion of the sociodrama as it symbolically represented Austria's governmental shift from that of a monarchy to a republic.

\subsubsection{Youth and Police in Philadelphia}

The use of role-playing techniques, psychodrama, sociodrama, and drama therapy seems to be well received by young people and has been covered by various other authors (Cahill, 2015; Cossa, 2006; Giacomucci, 2017; Jennings, 2014; Maier, 2002; Weber \& Haen, 2005). The elements of play, spontaneity, creativity, and social connection seem to highly compliment the developmental tasks of young people (Giacomucci, 2017). Cossa (2006) highlights specifically how sociodrama and psychodrama create opportunities for youth to explore new roles, practice social skills, express emotions, meet developmental needs, and experiment with new emerging aspects of identity.

My first personal experience of sociodramatic role-play in a community setting was as an observer at a community event in North Philadelphia. The event was focused on mitigating conflict and enhancing relationships between youth and police officers in the community. Many of the youth in the community felt as though they were being unfairly harassed by police officers or discriminated against due to their race or ethnicity while the police officers felt as though they were unfairly disrespected by the youth. The warming up process included a moderated discussion between the two groups and the voicing of difficult encounters between both groups. From there, the session moved into action enacting several of the described encounters. One of the most memorable was a described experience of youth feeling harassed by the police for hanging out on the sidewalk with friends.

The moderator invited three police officers from the group to play the roles of three youth hanging out together on the sidewalk. Then, one of the adolescents from the community volunteered and was enrolled into the police officer role. The situation was that the officer had been told to respond to a noise complaint in the 
neighborhood. As he approached the three kids, he respectfully asked them to be quiet, they responded telling him to stop harassing them and that they were not doing anything wrong. The police officer tried again to redirect them, this time with more firmness, asking them to go home. The kids protested louder with more energy and frustration at the officer. After multiple failed attempts, the teen playing the role of the police officer became visibly frustrated with the kids. The audience shared his frustration with outbursts of laughter which turned to nervous laughter when the kid role-playing as the police officer jokingly pretended to pull out a gun and threaten the three kids. Here, the moderator paused the scene and took the opportunity to de-role the auxiliaries and move into a discussion about the experience as it relates to the realities of the community.

The youth commented on their newfound insight into how they might unknowingly make police officers' jobs more difficult_especially how their reactions to law enforcement might increase the likelihood of violence. The discussion shifted to the reasons why teens might spend time on the street together which included acknowledging the high rates of household violence, drug abuse, and poverty in the community. The teenagers shared about their avoidance of going home because of these issues which provided the police with a more complete picture of the lives of the youth. Naturally, this increased understanding led to enhanced compassion and a softening of the police officers' attitudes toward the kids. The sociodramatic enactments had successfully allowed each group to role reverse with the other and enhance their understanding of the other group's experience. Though many issues persist between police and the community, this encounter depicts sociodrama's ability to improve intergroup relationships. Perhaps an indicator of the intervention's success was the friendly, but competitive basketball game between the youth and police that took place in the park after the community session.

A similar program is outlined in the Center for Court Innovation toolkit for police-youth dialogues (2015) which emphasizes the role-playing component of the program:

Role-plays-especially reverse role-plays where young people act as officers and vice versa - can help participants address challenging street interactions while having some fun. When playing officers, young people learn how difficult it can be to make quick decisions in fraught situations, while police playing young people get a taste of how intrusive questioning can feel. (p. 21)

In this publication, role-playing between police and youth was highlighted by researchers and observers as the favorite aspect of the program by both police and youth participants. 


\subsubsection{Sociodramatic Dialogue Between Generations in Baltimore City Barbershops}

Another use of sociodrama to explore and enhance intergroup relationships comes from the work of Joshua Lee, MSW, CP, a social worker and psychodramatist in Baltimore City who has created multiple innovative experiential approaches to community social work including ShopTalk: Share. Heal. Grow. ShopTalk is a project Joshua developed using Moreno's methods in urban barbershops with the African-American community after the 2015 Baltimore uprisings responding to police brutality (Lee, 2018). In his 2018 article about his approach, Lee writes that his experiential work in barbershops has explored various topics pertinent to the community including violence, addiction, relationships, trauma, and loss. He outlines a sociodramatic empty chair dialogue that emerged between the older and younger generations due to a comment from an older man that "those young people are lost these days". Seizing the opportunity for dialogue, Joshua pulls out an empty chair to represent young people and begins spontaneously facilitating the drama. From the role of the younger generation, someone exclaims "you all failed us!" As it emerges, the dialogue draws in participants within the barbershop as they become curious and warmed up, speaking from the various roles until the encounter moves to closure. Another enactment from the barbershop group centered on a man who wanted to psychodramatically speak to God in the other empty chair. He began to thank God for saving him from childhood trauma, addiction, incarceration, and violence as the rest of the group witnessed with reverence. Observers in the barbershop responded with a standing ovation, followed by general sharing of similarities and a sense of relief and gratitude for the chance to share their stories.

When a psychodrama or sociodrama really represents the issues in the group, it catches everyone's attention and pulls them into engagement with excitement, interest, and anticipation. Lee writes that "action methods in barbershops seemed to pull people into the conversation quickly, thereby causing deeper connections and heartfelt-experiences with 'strangers' to develop" (Lee, 2018, p. 146). Joshua highlights the importance of trusting the community to support each other and find their own answers within the sociodrama structure (J. Lee, personal communication, May 18th, 2020). Joshua notes that ShopTalk sessions have, at times, broken out into spontaneous dance and music - and that attendees often attend future communitybased psychodrama events. Joshua's work within the community strongly resembles the original methods of both the social work profession and the Morenean approach of meeting people where they are at. This involves going out into the community to where people live to be of service, rather than meeting individual clients in neatly organized professional offices. The use of Moreno's methods through ShopTalk incorporates a range of interventions focused on both social and emotional issues of individual protagonists, groups, and the larger community. 


\subsubsection{Crisis Intervention Training for Law Enforcement on Domestic Violence, Mental Health, and Addiction}

The use of sociodrama and role-play techniques has been used in training programs and events with law enforcement to both challenge biases about mental illness and domestic violence while also providing role training on more sensitive ways to respond (Buchanan \& Hankins, 1987; Buchanan \& Swink, 2017; Moreno, 2014). This use of Moreno's methods in training law enforcement was spearheaded by the St. Elizabeths Hospital prestigious psychodrama program which developed a collaboration with the Washington DC. Police Department in the 1970s. An objective was set to provide training for all Washington DC. police officers on family crisis intervention (Buchanan \& Swink, 2017). The popularity of this type of training program is evidenced by its promotion in many major national newspapers and its adaptation into training programs for other government agencies including the Federal Bureau of Investigation hostage negotiation team, Social Security Administration, the State Department, U.S. Army, U.S. Secret Service, Dulles Airport security, and the U.S. Capital Police.

Advocating for a new approach to domestic violence. The most successful training program of this nature was the Family Crisis Intervention Program, a collaboration between psychodramatists at St. Elizabeths Hospital and the Metropolitan Police Department of Washington DC. It was also the most extensive training program in the United States at that time (Hankins \& Buchanan, 1987). This program curriculum is outlined in the publication The Badge and the Battered, edited by Buchanan and Hankins (1987). This program emerged due to the problem of family violence, police officers' high rates of assault or death while responding to domestic violence calls, and critiques at nature of police officers' interventions (or lack of) (Callahan, 1987; Hankins, 1987). The program implemented sociodramatic role-play enactments so participants could experientially explore common family disturbance situations, potential family dynamics that lead to family conflict, and practice responding to these situations in different ways while also exploring their personal biases related to sexuality, gender, religion, family status, substance abuse, and mental illness (Chasnoff, 1987). The role-plays included consideration to non-verbal behavior and adhered to a five-phase intervention model-safety, diffusion, communication, resolution, and referral. Afterward, participants engaged in a discussion about which interventions seemed most effective and their own action insights during the process. Multiple studies were conducted evaluating the impact of the program which concluded that (1) there was a significant reduction of assaults on police who were trained by the program (Buchanan \& Hankins, 1983), (2) significant changes in police attitudes about domestic violence and their ability to respond to it (Buchanan \& Perry, 1985), (3) an increased ability to defuse conflictual situations (Bandy, Buchanan, \& Pinto, 1986), and (4) an overall improvement in communication skills, role repertoire, and spontaneity in responses (Hankins \& Buchanan, 1987). In describing the program, the Chief of Police commented that "I am convinced that our officers are providing more sensitive intervention; and as a result, are more capable in handling 
family disturbances. The significant reduction in assaults on police officers is a direct result of this new competence" (Buchanan \& Hankins, 1987, n.p.). The utility of sociodrama and role training to improve behavioral responses is highlighted by this project which created lasting change in the law enforcement community and the communities in which they serve.

Challenging perceptions on mental illness and addiction. The success of the Family Crisis Intervention Program described above resulted in many later programs including the training of police in Pennsylvania using sociodramatic methods to challenge perspectives on mental illness. This project advocated for less criminalization and more human police treatment of those suffering from addiction and mental health issues. After didactic presentations are offered by facilitators on common mental health disorders, a sociodramatic role-play ensues. One such example comes from the work of David Moran, LCSW, CADC, TEP with a behavioral health crisis intervention unit of police officers in the Philadelphia suburbs.

The group is exploring their response as police officers to an escalated situation which involves an individual with schizophrenia. Police participants in the group are cast in the various roles including the responding officers, the victim, the aggressive person suffering from schizophrenia, and the multiple schizophrenia-related voices that this individual is experiencing. The impact of the schizophrenic voices on the individual become apparent when externalized through the role-play as the participant in the role of this person attempts to communicate with others in the scene while also hearing internal voices. In the role-play, law enforcement agents have an opportunity to practice different methods of responding to the individual with severe mental illness to determine the most effective approach. This process allows the responding officers to develop an experiential understanding of the internal reality of someone with schizophrenia so that they can respond on the job with more empathy and understanding.

The training program also uses a similar sociodramatic training vignette focused on persons with addictive disorders where a similar scene is enacted but with auxiliaries playing the roles of "the voice of addiction," "alcohol," "drugs," or "drug cravings". While many have biases against people with addictions, the role-play also helps participants develop a better understanding and sense of empathy for the suffering of those inflicted with addictions. In this module, the high rates of alcohol and substance abuse within law enforcement communities are also acknowledged as a way of helping trainees cultivate empathy and prevent an "us versus them" mentality. Overall, the program helps to mitigate the tendency to stigmatize or dehumanize persons with severe mental illness or addictions, enhance understanding and empathy, and increase practical communication skills for officers when communicating with persons with addictions and severe mental illness.

Research on a similar police training program demonstrated a significant increase in recognition of mental health issues, improved efficiency dealing with mental illness, and decreased physical altercations and weapon-involved interactions with mentally ill individuals (Krameddine, DeMarco, Hassel, \& Silverstone, 2013). The outcomes of this study suggested that a one-day training for police costed about 
$\$ 120$ per officer but resulted in more than $\$ 80,000$ in savings over the next 6 months because of the improved interpersonal skills of officers interacting with mentally ill individuals in the community. Other studies focused on using role-playing simulations to improve police interactions with mentally ill individuals have also produced positive results (Bonfine, Ritter, \& Munetz, 2014; Krameddine \& Silverstone, 2015; Reuland \& Schwarzfeld, 2008; Silverstone, Krameddine, DeMarco, \& Hassel, 2013; Watson, Morabito, Draine, \& Ottati, 2008).

\subsection{Role Training for Community Empowerment}

The use of role-playing to practice for future situations or refining interactive skills is described as role training (Blatner, 2000). The utilization of role training has many applications in community work as it emphasizes learning and experiential skills practice while generally being less cathartic than other psychodrama scenes. Role training is future-oriented toward hoped-for outcomes, so it is also much less anxiety producing than other types of role-play scenes. Role training is already being used regularly in community settings though it is usually simple referred to as "role-playing" or "simulations". The next set of examples will focus specifically on using role training simulations to empower community members to advocate for themselves, others, and their community.

\subsubsection{Know Your Rights Role Training for Undocumented Immigrant Communities}

As noted previously, role-play and role training are frequently used by community organizers, especially with immigrant communities. Know your rights sessions for immigrant communities have been offered by community leaders and organizations around the country for quite some time (Tipler \& Gates, 2019) but became especially important after the presidential election of Donald Trump and the increased threat experienced by undocumented communities in the United States. These sessions generally are facilitated by community organizers collaborating with attorneys specializing in immigration law and interpreters/translators to provide accurate and accessible information related to the legal rights of undocumented immigrants. The sociodramatic role-plays begin after a didactic information session focused specifically on the legal rights of undocumented persons when encountering Immigration and Custom Enforcement (ICE) authorities.

This specific example comes from the work of Maria Sotomayor-Giacomucci and the Pennsylvania Immigration and Citizenship Coalition (PICC) (see their online toolbox for more info-(www.paimmigrant.org/toolbox/know-your-rights). A common know your rights simulation that is employed is that of an ICE agent 
appearing at the home of an immigrant family requesting that they open the door and provide information to authorities. After being informed of their legal obligations in this situations, and possible responses, the role-play simulations begin with the purpose of role training community members on how to respond. Community members are taught that they do not need to open the door unless presented with a signed judicial warrant. The differences between judicial warrants and ICE administrative warrants are explained, and community members are instructed to inspect the warrant for the listed address, name, and a signature by a judge. If a judicial warrant with correct information is not presented, community members are informed that they are within their rights not to open the door and instead to call a lawyer and/or a local immigrant rights organization. If a judicial warrant is presented by ICE agents, then community members are instructed to comply but only for the names of the people on the warrant - that they should leave the home and lock the door as not to give ICE the chance to question others in the home who were not listed on the warrant. After the information has been conveyed, then the role training phase of the session begins, and community members practice role-playing the situation of an ICE agent knocking on someone's door while participants practice their newly learned responses. After the role training practice, participants de-role and engage in a debriefing phase before the session ends.

Participants often report a sense of relief at learning that they do have rights as undocumented people in the country. Many undocumented countries have migrated from countries with governments that are much more authoritarian than those in the United States, and they simply are not aware of their rights or were never informed of them. While they continue to have concerns and fears related to the uncertainties created by their status, they feel relief at knowing they do not have to open the door for ICE except in specific circumstances. Community members report feeling empowered to protect themselves, their families, and communities - that they now feel like they have the ability and permission to resist. Tipler \& Gates' (2019) study of the impact of know your rights trainings with undocumented communities validates that participation: (1) reduced fear and increased a sense of power or control, (2) reduced stigma/isolation and increased social support, and (3) increased a sense of dignity and empowerment. This role training piece demonstrates the operationalization of the provided know your rights information which effectively empowers community members and helps reduce anxieties or uncertainties. Perhaps the visual component of the demonstration also helps transcend possible language barriers for community members who speak different languages. Instead of only transmitting information through verbal or spoken words, the information is embodied in the scene. 


\subsubsection{MSW Students Responding to Racism and Microaggressions}

The utilization of role training simulations can help participants develop competency and skill responding to racism and microaggressions in everyday life while enhancing cultural competencies (Colvin, Saleh, Ricks, \& Rosa-Davila, 2020; Lee, Blythe, \& Goforth, 2009; Pope, Pangelinan, \& Angela, 2011; Schreiber \& Minarik, 2018). The following example comes from a guest lecture by this author at the University of Pennsylvania School of Social Policy \& Practice's MSW course on racism. After a series of sociometric warm-ups based on the tenants of critical race theory (Delgado $\&$ Stefancic, 2017), participants were invited to create concentric circles to participate in a role-playing process called "The Role Wheel". In this exercise, one member from the inner circle and the outer circle are paired together, each assigned with a role by the facilitator. The facilitator may also provide context related to the scene or the goal of the enactment before participants simultaneously initiate a spontaneous interaction with their partners. Each enactment is kept short, to a minute or two at most with participants being instructed to de-role, say good-bye to their partner, and greet their new partner as the outer circle participants are directed to move one space to their left. Then, another set of roles are provided for each group, and a new spontaneously improvised scene enacted. As noted in previous sections, it helps to begin with simple, fun, and positive prompts/roles before moving into more difficult prompts, and ending with positive, future-oriented content. The following roles were offered to participants:

\section{First Scene}

Role 1: Someone considering social work school.

Role 2: MSW student offering insight into benefits/difficulties of being an MSW student.

\section{Second Scene}

Role 1: Social worker taking the position that race has more impact on one's life than class.

Role 2: Social worker taking the position that class has more impact on one's life than race.

\section{Third Scene}

Role 1: MSW student advocating for new anti-racist policies on campus.

Role 2: Dean of a social work school.

\section{Fourth Scene}


Role 1: Group therapy client who unknowingly said something offensive regarding race.

Role 2: Social worker leading the group addressing the accidental microaggression.

\section{Fifth Scene}

Role 1: MSW student with newfound commitment to address racism in everyday life.

Role 2: Student's intoxicated uncle at a family party making a racist comment.

\section{Sixth Scene}

Role 1: African-American client who feels hurt or frustrated by something insensitive their therapist said in previous session.

Role 2: Clinical social worker making amends and being accountable for their microaggression in previous session.

\section{Seventh Scene}

Role 1: NASW award recipient for anti-racist work congratulating another award winner.

Role 2: NASW award recipient for anti-racist work congratulating another award winner.

The scenes started with roles that each student would be familiar with to help with the warming up process and establish a sense of connection, playfulness, and safety with the role-playing exercise. Then, we moved into an intellectually based role-play arguing an opinion related to the content of the racism class. Next, students engaged in a series of role-plays focused on responding to microaggressions or advocating for anti-racist policies in situations related to their experience as students beginning to work in the field. In addition to rotating partners with each scene, it is important to note that the nature of the roles was intentionally switched with each emotionally charged prompt. For example, in scene three, group one played the role of a student advocating for anti-racism policies, while group two played the role of the social work school's dean. In the following scene, the roles were reversed in a sense as group two then played the role of a social worker addressing a microaggression, while group one played the role of a client. The final scene offers a chance for participants to end on a positive note and through the roles, recognize each other for their willingness to engage in the difficult and often uncomfortable process of learning to address racism in everyday life.

While it helps to prepare a list of roles and scenes prior to facilitating this process, it is also important for the facilitator to maintain awareness and attunement of how the group is experiencing the scenes and their level of spontaneity. A less warmed up and less spontaneous group might need more prompts that are simple and easy 
before offering more emotionally difficult prompts. If presented with this situation, the facilitator could offer another prompt that is less emotionally charged, or roles that are more fantasy-based. For example, if the group depicted above was lacking in their warm-up, the following roles could have been proposed to cultivate more playfulness and aesthetic distance:

Role 1: Draco Malfoy from the Harry Potter series arguing that only "pure bloods" should be admitted to Hogwarts School for Witchcraft \& Wizardry.

Role 2: Harry Potter advocating that the admissions process should be open to all regardless of their ancestry.

This scene would have moved the process into fantasy roles that many students would be familiar with while keeping the content of the dialogue and role dynamics congruent with the topic of student advocates addressing racism. Because the roles are fantasy-based, it would have reduced anxiety for students while increasing spontaneity and playfulness.

After the session, participants de-role, return to their seats, and the sharing phase of the group begins. Students are prompted to share what it was like for them to participate in the series of role-plays, including what was difficult and what was helpful. Multiple students in this session commented on how some of the role-plays were uncomfortable but challenged them to grow personally and professionally. Some commented that they found the regular discussion about racism limiting compared to the sociodramatic role-plays which helped them to operationalize their intellectual learning into practical real-world situations. This is a simple experiential teaching structure could be integrated into anti-racism social work courses to enhance the learning experience of students.

\subsubsection{Empowering Community Members to Advocate to Funders, Politicians, and Employers}

Advocacy, empowerment, and social work are intricately linked (Mackay, 2007). Advocacy is a form of both structural and psychological empowerment that challenges the current distribution of power or resources (Thompson, 2002). "Both the intent and outcome of such advocacy should be to increase the individual's sense of power; help them feel more confident, to become more assertive and gain increased choices" (Brandon, 1995, p. 1). Role training simulations offer participants empowerment through increased sense of personal agency and the ability to advocate for themselves, others, and their communities. The use of role-play simulations to teach advocacy skills has been highlighted in multiple contexts and with multiple populations (Burns, 1995; Gillespie, Brown, Grubb, Shay, \& Montoya, 2015; Lopez, 2016; Ruyters, Douglas, Law, \& Siew, 2011; Sievert, Cuvo, \& Davis, 1988). Following are three examples of role training advocacy skills in community social work contexts. 
Advocating for policy change to benefit communities. Role training exercises are used regularly by community organizers and social workers to provide role training experiences for participants warming up to advocate for funding or policy change from those with financial or political power. The previous subsection describing MSW students responding to microaggressions included a depiction of this in scene three which positions participants in the roles of a university dean and a student advocating for anti-racist policy changes. This same structure can be used to create opportunities for participants to practice advocating to funders, legislators, school board members, or any other person in power. The structure can simply be modified to fit the issues and political actors related to the community at hand. Participation in role training for advocacy to funders or politicians offers individuals a chance to practice their scripts, learn by observing other's enactments, and develop confidence with their advocacy skills.

Advocating to insurance companies. With the rise of managed care, social workers find themselves regularly advocating for clients to insurance companies to cover medical and mental health services. While the previous role training descriptions did not depict the use of role reversal, the development of advocacy skills with insurance companies can be enhanced through role reversal. The following vignette comes from an ongoing educational group of social workers working in inpatient addiction treatment.

One social worker begins to express their frustration and anger toward insurance companies for unjustly refusing to authorize more days in treatment for his clients. The other participants begin to empathize and share their own irritation at insurance providers. Noticing the group's organic warm-up, the facilitator seizes the opportunity to move the group into a role training enactment with the goals of expressing frustrations, increasing insight, and improving advocacy skills. The facilitator invites the social worker who raised the topic to openly express his anger and frustration to an empty chair representing the insurance company. Already warmed up, he begins to angrily speak to the insurance company in the empty chair. Other participants are invited to offer doubling statements, while channeling their own frustrations. After the anger catharses began to subside, the facilitator instructs the protagonist to role reverse with a case manager from the insurance company. The director then begins to interview the insurance case manager inquiring about their ability to authorize more time for treatment. In the process, it becomes apparent that the case manager of the insurance company desires to authorize time in treatment for patients but can only do so when medical necessity has been demonstrated through adequate documentation by the social worker. The facilitator moves the session toward closure and de-roling, after which a dialogue emerges between participants about best practices for documenting and articulating medical criteria to insurance providers. At the completion of the session, the social work participants expressed their newfound insights into how to advocate to their clients' insurance companies with increased knowledge, sophistication, and confidence. A new paradigm emerges-instead of feeling like they are working against the case manager from the insurance company, they see an opportunity to work together with the case manager to help the mutual client. 
Learning to advocate for self. While social workers develop professional skills for advocating for others, we sometimes have trouble advocating for ourselves. Social workers are underpaid compared to their counterparts with the same educational level in other helping professions (Hughes, Kim, \& Twill, 2018; Wright, 2010). Numerous researchers have written about social workers lack of self-advocacy when it comes to their own salary negotiations (Schweitzer, Chianello, \& Kothari, 2013; Wermeling \& Smith, 2009). A large disparity (\$11,000 difference between median salaries) exists between salaries of men and women social workers (NASW, 2010), though studies have also uncovered that men are four times more likely to ask for salary increases than women (Babcock \& Laschever, 2009). Role training for salary negotiations and increased financial compensation offers an avenue for empowering social workers to advocate for themselves.

Similar to the previous example, this vignette describes the use of role reversal in a role training enactment to cultivate action insights. The role reversal allows participants to step into the shoes of the other and expand their sense of the other person's needs, wants, or goals in the encounter. The situation describes the use of role-playing techniques to help social workers practice advocating for self at a contract or salary negotiation. Participants are invited to choose a real or imagined situation to practice advocating for themselves. After choosing another group member to play the role of their supervisor, they are invited to begin the dialogue. Participants are instructed to role reverse into the role of their supervisor, hearing their argument replayed through the eyes of the other. After considering the supervisor's organizational limitations and needs, a response is provided, and the dialogue continues with back and forth role reversals. This action vignette offers social workers the chance to step into the shoes of their supervisor to consider the perspective of the other and to develop insight into what the organization may need to hear in order to initiate a salary increase. While participants appeared more focused on conveying the value they offer to their clients initially, the action insights of the role-play helped them consider and articulate the value they offer the organization, especially in terms of the financial bottom line. This example comes from the author's personal experience working with social work supervisor and psychodramatist, David Moran, LCSW, CADC, TEP.

\subsection{Conclusion}

The aforementioned examples demonstrate the implementation of sociodrama roleplays focused on intergroup relations and role training for community empowerment. Drama and theater offer community social workers useful tools for sessions focused on social activism and social change. Through simulated role-plays, a social worker facilitating community sessions can offer engaging structures with proven effectiveness at teaching skills for communication, behavioral rehearsals, social skills, and advocacy. The use of drama and theater in community life can be traced back to the origins of the social work field and various ancient cultures. The application of Moreno's methods in community work positions community members as therapeutic 
and educational agents for each other while bringing the content of the session to life in an embodied process. This is congruent with Moreno's early visions of Sociatry, the Theater of Spontaneity, a therapeutic society, and group psychotherapy. This author joins others who advocate for sociodrama as the most appropriate Morenean method for community work due to its educational power.

\section{References}

Aristotle. (1951). Poetics (S. H. Butcher, Trans.). Mineola, NY: Dover Publications.

Babcock, L., \& Laschever, S. (2009). Women don't ask: Negotiation and the gender divide. Princeton University Press.

Bandy, C., Buchanan, D. R., \& Pinto, C. (1986). Police performance in resolving family disputes: Evaluating the effectiveness of a training program. Psychological Reports, 58, 743-756.

Blatner, A. (2000). Foundations of psychodrama: History, theory, and practice (4th ed.). New York City: Springer Publishing Company.

Bonfine, N., Ritter, C., \& Munetz, M. R. (2014). Police officer perceptions of the impact of crisis intervention team (CIT) programs. International Journal of Law and Psychiatry, 37(4), 341-350.

Brandon, D. (1995). Peer support and advocacy: International comparisons and developments. In R. Jack (Ed.), Empowerment in community care (pp. 108-133). Boston: Springer.

Buchanan, D. R., \& Hankins, J. M. (1983). Family disturbance intervention program. FBI Law Enforcement Bulletin, 52, 10.

Buchanan, D. R., \& Hankins, J. (1987). Introduction. In D. R. Buchanan \& J. Hankins (Eds.), The badge and the battered: A family crisis intervention training manual for law enforcement agencies. Washington, DC: Government of the District of Colombia.

Buchanan, D. R., \& Perry, P. A. (1985). Attitudes of police recruits towards domestic disturbances: An evaluation of amily crisis intervention training. Journal of Criminal Justice, 13, 561-572.

Buchanan, D. R., \& Swink, D. F. (2017). Golden age of psychodrama at Saint Elizabeths hospital (1939-2004). The Journal of Psychodrama, Sociometry, and Group Psychotherapy, 65(1), 9-32.

Burns, R. P. (1995). Teaching the basic ethics class through simulation: The Northwestern program in advocacy and professionalism. Law and Contemporary Problems, 58(3/4), 37-50.

Cahill, H. (2015). Rethinking role-play for health and wellbeing: Creating a pedagogy of possibility. In K. Wright \& J. McLeod (Eds.), Rethinking youth wellbeing (pp. 127-142). Singapore: Springer.

Callahan, M. L. (1987). The evolution of a program: The DC metropolitan police family crisis intervention training project. In D. R. Buchanan \& J. Hankins (Eds.), The badge and the battered: A family crisis intervention training manual for law enforcement agencies (pp. 3-10). Washington, DC: Government of the District of Colombia.

Center for Court Innovation. (2015). Guide for improving relationships and public safety through engagement and conversation: Police-youth dialogues toolkit. Washington, DC: Office of Community Oriented Policing Services.

Chasnoff, P. (1987). Curriculum. In D. R. Buchanan \& J. Hankins (Eds.), The badge and the battered: A family crisis intervention training manual for law enforcement agencies (pp. 19-46). Washington, DC: Government of the District of Colombia.

Colvin, A. D., Saleh, M., Ricks, N., \& Rosa-Davila, E. (2020). Using simulated instruction to prepare students to engage in culturally competent practice. Journal of Social Work in the Global Community, 5(1), 1.

Cossa, M. (2006). Rebels with a cause: Working with adolescents using action techniques. Jessica Kingsley Publishers.

Delgado, R., \& Stefancic, J. (2017). Critical race theory: An introduction (Vol. 20). New York: NYU Press. 
Freedley, G., \& Reeves, J. A. (1964). A history of the theatre. New York, NY: Crown Publishers Inc.

Giacomucci, S. (2017). The sociodrama of life or death: Young adults and addiction treatment. Journal of Psychodrama, Sociometry, and Group Psychotherapy, 65(1), 137-143. https://doi. org/10.12926/0731-1273-65.1.137.

Gillespie, G. L., Brown, K., Grubb, P., Shay, A., \& Montoya, K. (2015). Qualitative evaluation of a role-play bullying simulation. Journal of Nursing Education and Practice, 5(7), 73.

Greeb, M. N. (2019). The psychodrama of São Paulo City. In Z. Figusch (Ed.), From one-to-one psychodrama to large group socio-psychodrama, (2nd ed., pp. 223-231). UK: lulu.com.

Hankins, J. (1987). Police response to family violence. In D. R. Buchanan \& J. Hankins (Eds.), The badge and the battered: A family crisis intervention training manual for law enforcement agencies (pp. 1-2). Washington, DC: Government of the District of Colombia.

Hankins, J., \& Buchanan, D. R. (1987). Results and conclusions. In D. R. Buchanan \& J. Hankins (Eds.), The badge and the battered: A family crisis intervention training manual for law enforcement agencies (pp. 51-52). Washington, DC: Governemnt of the District of Colombia.

Hecht, S. (1982). Social and artistic integration: The emergence of hull-house theatre. Theatre Journal, 34(2), 172-182.

Hughes, J. C., Kim, H., \& Twill, S. E. (2018). Social work educational debt and salary survey: A snapshot from Ohio. Social Work, 63(2), 105-114.

Hunter, D., \& Lakey, G. (2004). Opening space for democracy. Training manual for third-party nonviolent intervention. Philadelphia: Training for Change.

Jemal, A., Urmey, L. S., \& Caliste, S. (2020). From sculpting an intervention to healing in action. Social Work with Groups. https://doi.org/10.1080/01609513.2020.1757923.

Jennings, S. (Ed.). (2014). Dramatherapy with children and adolescents. London: Routledge.

Krameddine, Y., DeMarco, D., Hassel, R., \& Silverstone, P. H. (2013). A novel training program for police officers that improves interactions with mentally ill individuals and is cost-effective. Frontiers in Psychiatry, 4, 9.

Krameddine, Y. I., \& Silverstone, P. H. (2015). How to improve interactions between police and the mentally ill. Frontiers in Psychiatry, 5, 186.

Leahy, R. A. (2008). The theatre as an examination of power: Combining political theory and theatre history (Honors theses, 1576). Retrieved May 7th, 2020 from https://digitalworks.union. edu/theses/1576.

Lee, E. K. O., Blythe, B., \& Goforth, K. (2009). Teaching note: Can you call it racism? An educational case study and role-play approach. Journal of Social Work Education, 45(1), 123-130.

Lee, J. S. (2018). The use of psychodrama and sociodrama in barbershops. The Journal of Psychodrama, Sociometry, and Group Psychotherapy, 66(1), 141-146.

Lopez, N. J. (2016). Effects of a self-advocacy intervention on the ability of high school students with high incidence disabilities to advocate for academic accommodations (Theses and dissertations, 582). Retrieved from https://ir.library.illinoisstate.edu/cgi/viewcontent.cgi?article=1582\&contex $\mathrm{t}=$ etd

Mackay, R. (2007). Empowerment and advocacy. In J. Lishman (Ed.), Handbook for practice learning in social work and social care (2nd ed., pp. 269-284). London: Jessica Kingsley Publishers.

Maier, H. W. (2002). Role-playing: Structures and educational objectives. The International Child and Youth Care Network, 36.

McCammon, L. A. (2007). Research on drama and theater for social change. In L. Bresler (Ed.), International handbook of research in arts education (pp. 945-964). Rotterdam: Springer.

Moreno, J. D. (2014). Impromptu Man: J. L. Moreno and the origins of psychodrama, encounter culture, and the social network. New York, NY: Bellevue Literary Press.

Moreno, J. L. (1940). Mental catharsis and the psychodrama. Sociometry, 3, 209-244.

Moreno, J. L. (1943). The concept of sociodrama. Sociometry, 6(4), 434-449.

Moreno, J. L. (1972). Psychodrama (Vol. 1, 4th ed.). New York: Beacon House. 
Moreno, J. L. (2019). In E. Schreiber, S. Kelley, \& S. Giacomucci, (Eds.), The autobiography of a genius. United Kingdom: North West Psychodrama Association.

National Association of Social Workers. (2010). 2009 compensation and benefits study: Summary of key compensation findings. Washington, DC: NASW.

Oliveira, E. C. S., \& Araújo, M. F. (2012). Aproximações do teatro do oprimido com a Psicologia e o Psicodrama. Psicologia: Ciencia e Profissao, 32(2), 340-355.

Pope, M., Pangelinan, J. S., \& Coker, A. D. (Eds.). (2011). Experiential activities for teaching multicultural competence in counseling. Alexandria, VA: American Counseling Association.

Reuland, M. M., \& Schwarzfeld, M. (2008). Improving responses to people with mental illnesses: Strategies for effective law enforcement training. Justice Center, the Council of State Governments.

Ruyters, M., Douglas, K., \& Law, S. F. (2011). Blended learning using role-plays, wikis and blogs. Journal of Learning Design, 4(4), 45-55.

Schreiber, J. C., \& Minarik, J. D. (2018). Simulated clients in a group practice course: Engaging facilitation and embodying diversity. Journal of Social Work Education, 54(2), 310-323.

Schweitzer, D., Chianello, T., \& Kothari, B. (2013). Compensation in social work: Critical for satisfaction and a sustainable profession. Administration in Social Work, 37(2), 147-157.

Schlossman, D. A. (2002). Actors and activists: Politics, performance, and exchange among social worlds. Psychology Press.

Shank, T. (1982). Theatre of social change. In T. Shank (Ed.), American alternative theatre (pp. 5090). London: Macmillan Modern Dramatists. Palgrave.

Sievert, A. L., Cuvo, A. J., \& Davis, P. K. (1988). Training self-advocacy skills to adults with mild handicaps. Journal of Applied Behavior Analysis, 21(3), 299-309.

Silverstone, P. H., Krameddine, Y. I., DeMarco, D., \& Hassel, R. (2013). A novel approach to training police officers to interact with individuals who may have a psychiatric disorder. Journal of the American Academy of Psychiatry and the Law Online, 41(3), 344-355.

Sternberg, P., \& Garcia, A. (2000). Sociodrama: Who's in your shoes? (2nd ed.). Westport, CT: Praeger Publishers.

Thompson, N. (2002). Social work with adults. In R. Adams, L. Dominelli, \& M. Payne (Eds.), Social work: Themes, issues, and critical debates (2nd ed., pp. 287-307). Basingstoke: Palgrave Macmillan.

Tipler, K., \& Gates, A. B. (2019). Rights education without rights? Rights workshops and undocumented immigrants in the US. Journal of Ethnic and Migration Studies, 1-17.

Watson, A. C., Morabito, M. S., Draine, J., \& Ottati, V. (2008). Improving police response to persons with mental illness: A multi-level conceptualization of CIT. International Journal of Law and Psychiatry, 31(4), 359-368.

Weber, A. M., \& Haen, C. (Eds.). (2005). Clinical applications of drama therapy in child and adolescent treatment. New York: Brunner-Routledge.

Wermeling, L., \& Smith, J. (2009). Retention is not an abstract notion: The effect of wages and caretaking. Journal of Social Service Research, 35(4), 380-388.

Wright, G. (2010). NASW's new study provides better information on social work salaries. Retrieved from https://www.socialworkers.org/News/News-Releases/ID/356/NASWsNew-Study-Provides-Better-Information-on-Social-Work-Salaries. 
Open Access This chapter is licensed under the terms of the Creative Commons Attribution 4.0 International License (http://creativecommons.org/licenses/by/4.0/), which permits use, sharing, adaptation, distribution and reproduction in any medium or format, as long as you give appropriate credit to the original author(s) and the source, provide a link to the Creative Commons license and indicate if changes were made.

The images or other third party material in this chapter are included in the chapter's Creative Commons license, unless indicated otherwise in a credit line to the material. If material is not included in the chapter's Creative Commons license and your intended use is not permitted by statutory regulation or exceeds the permitted use, you will need to obtain permission directly from the copyright holder.

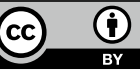

